\title{
The Fundamental Deviation and the Riddle of Manipulation: A Critical Analysis in the Context of Bangladesh Stock Market Crash in 2010-11
}

\author{
Md. Toufique Hossain
}

Department of Accounting \& Information Systems, University of Dhaka, Bangladesh

\begin{abstract}
The capital market in Bangladesh does not always act based on the fundamentals. Fundamental means the set of ethics, principles, guidance, various market instruments and well structural set up that helps the stock market for operating well. Structural weakness is a thing which may ruin the market base or fundamentals. But the capital market as part of the economy should function based on the fundamental norms, principles and proper rules and regulations. Otherwise, there may be some detrimental effects on the market. Stock market anomalies bring harm not only to destroy market fundamentals but also to spread manipulation inside the stock market. Moreover, the recent stock market crash in 2010-11 was the biggest shock for the 3.3 million innocent and small investors in the capital market of Bangladesh. A section of greedy investors resorted to manipulation at different levels to cash in on the lack of small investors' proper knowledge about market fundamentals. The excessive fraudulent activities of the unscrupulous manipulators just hastened the fall of the market. So, much of the focus of this study has been put on the causes and consequences of the fundamental deviation and the riddle of manipulation based on the relevant facts and figures.
\end{abstract}

Key words: Anomalies, Capital market, Fundamentals, Stock market, Structural weakness, Crash, Manipulation

JEL Classification Code: E44, G10

\section{INTRODUCTION}

The stock market in Bangladesh is at still a primeval stage of development. The fundamentals are very flimsy and fragile. The general investors are not knowledgeable. All the required market instruments are not there to protect the interest of investors. As a result, panic, fascination and trouble, apart from other factors, have characterized the market over the years. The Dhaka Stock Exchange (DSE) experienced massive price volatility in 2010-11. (Hossain, 2011)

Bangladesh stock market has a chequered history. Dhaka Stock Exchange (DSE) started its journey as an incorporated body in 1954. However, formal trading began in 1956. Trading remained suspended during the 19711976 period because of the liberation war and the socialist policy stance of the immediate post-liberation government and resumed in 1976 (Rayhan et al, 2011).

There was a big bubble in 1996 followed by a catastrophic crash. Dhaka Stock Exchange (DSE) index jumped from 957 on November 02, 1996 to a record high of 3649 on November 05, 1996. The index continued a downhill march thereafter with the lowest level record on at 463 on May 03, 1999. Since then the market remained in a state of doldrums. It started on a path of resurgence from 2003 (Islam, 2005).

The stock markets of Bangladesh witnessed another bout of wild crash in 2010. The general index of DSE stood at
4535 at the end of December 2009, nearly doubled in less than a year to 8912 on December 05, 2010, suffered drastic loss of more than 1200 points over a period of two days to dip to 6499 one day in January 2011 and then regained more than 500 points on the next day of the month to reach 7512 following some policy pronouncements by Securities and Exchange Commission (SEC) and the Bangladesh bank. The index was 7378 on January 17, 2011. The downward march continued thereafter. As of now, index seems to have reached unjustifiably low level equalizer at around 4500. (Islam, 2014)

Bangladesh's capital market already experienced two massive debacles. The first market plunge happened in 1996 when a spurt of foreign investments in the capital market was greeted with withdrawal of the lock-in system leaving at risk the small investors doing paper-based trading at the kerb market. What is to be noted is that after the 1996 stock market crash, the authorities in Bangladesh's capital market adopted a lot of market-friendly policies, but those failed to avert the second big stock market crash which happened in the fiscal year 2010-11. (Hossain, 2014). Besides that, as per the analysis of the capital market behavior, a number of anomalies, weaknesses and constraints were observed during the second stock market crash. In the primary market, which deals with securities, a range of toxic elements were blamed for it. These include misuse of book building method, placement shares, direct listing and problems with audit reports. In the secondary 
market, which deals with stocks, bond options and futures, there were different toxic elements, like split shares, margin loans, serial trading and issuance of right shares. Furthermore, over-exposure of banks, omnibus accounts, insider trading, anomalies in $\mathrm{BO}$ account and the restricting nexus of big players like SEC, DSE/CSE \& political leaders also played their part in hastening the debacle. (Hossain, 2011)

After the first market crash in 1996, the government came forward to make it safe and secure and introduced an advanced technology-based transaction system instead of the paper-based trading system. Other measures including software surveillance were also taken. So, it took over a decade for the market to recover. About 12 years after the crash the index rose beyond the 1996 pre-crash high. However, the market again saw an unusual slide in 201011. The second stock market plunge occurred after the main index had attained close to 9,000 points from over 3,000 without any logical reason. What is important to note is that the second crash happened, though some preventive measures were taken after the first crash. There was no problem with the preventive measures taken for the market, including automation and surveillance software. Everything worked well. Then why did the second crash happen?

There was a lack of coordination among the BSEC, the central bank and the Ministry of Finance that were working for betterment of the market. So the market crashed for the second time. However, the stock market still continued to witness ups and downs and volatility that proved that manipulation was always taking place there.

Market crisis of 2010-11, a huge number of small investors lost their hard-earned money. It left them in the abyss of miseries. Definitely the manipulators ruined the market and left it as frail as glass. To satisfy their greed, the manipulators played a trick. In 2009, they took the market to a sky-high. Manipulators attracted small investors to the market in 2010 until the beginning of the biggest fall of it. In 2011 also, the market was not free from any act of manipulation. Reforms then could not be carried out up to the expectation because of their influences.

Moreover, if the market does not function as per the fundamentals, it causes harm to not only the daily trading but also the technical working of it. The capital market scenario in Bangladesh from December, 2010 to a couple of months into the FY 2012-13 had been very awful. The problems arose due to two factors: (1) Market anomalies, and (2) Market manipulation.

\section{OBJectives OF THE STUdY}

The main objectives of the study are:

- To discuss the concept of stock market anomalies and it's factors ;

- To interpret the different type of stock market anomalies;

- To discuss the other sensitive issues regarding market fundamental:
- To identify five major steps leading to market manipulation;

- To draw a conclusion based on the findings that I will get and will try to contribute by providing feedback or recommendation.

\section{Materials AND Methodologies}

Mainly my study consists of secondary data. Most Secondary data came from "Share Research magazine".

Secondary Source: The secondary data have collected from the Several International Journals, Publications, Reports as well as different websites including DSE website. To clarify different conceptual matters different articles have collected from: Journals, Internet, etc.

Data Processing

After collection of the raw data using the following computer packages had done editing and processing

- MS-Excel

- MS-Word

Data Analysis

The classified and tabulated data had been analyzed elaborately in a number of tables in an analysis part. Necessary percentages and averages calculated and the analyzed results describe step by step.

- Annual reports of DSE and DSE monthly review.

- Market pulse by LBSL

- Journal materials available at the DSE library,

- Various books articles, compilations etc.

\section{REVIEW OF LITERATURE}

There are a few numbers of research reports and theoretical works on the fundamental deviation and the riddle of manipulation. According to the requirement for this paper, I have reviewed several International and local literatures which include International Journals, Reports as well as Publication. These sorts of literature were published by different researchers through different institution from different part of the world.

The first reviewed literature was an International research journal named "The Stock Market Manipulations" conducted by (Aggarwal, Minnesota; and Wu, Houston). Here I have found that theory and evidence of stock price manipulation. The second reviewed literature was an International research paper topic The "A Framework for the Analysis of Market Manipulation" conducted by (LEDGERWOOD and. CARPENTER, Brattle Group).

Here I have found that the behavior of market manipulation.

The third reviewed literature was a local news paper article "Bangladesh scenario: Bubbles and busts" by (Islam,2014) has identified some crutial factors including (a)Asymmetry of information,( b) Adverse selection, and, (c) Moral hazard. In addition, to the above factors, market manipulation has also been cited a cause of instability said by (Islam, 2014). 
All the necessary references for the above literature review are given to bibliography.

\section{SIGNIFICANCE OF THE STUDY}

Stock Market is a very significant part for any country. Actually stock market is a part of a financial market. In Bangladesh there are two stock exchanges exist currently Dhaka Stock Exchange Limited \& Chittagong Stock Exchange Limited. But still the stock market of Bangladesh is a very little portion of the whole economy. Due to that it cannot plays important role in the economy like other country's stock market. However, there are many factors exists in the market that directly or indirectly affect the stock market to change the stock price over the time.

This study is to identify the causes and consequences of the fundamental deviation and the riddle of manipulation which are really responsible to stock market crash during 2010-11.

So that it will be an effective innovation for the economist, business persons, faculty members and market investors can be gained a good knowledge about the stock market anomalies.

\section{SYNOPSIS OF MARKET ANOMALIES}

The Merriam-Webster's Collegiate Dictionary defines an anomaly as a deviation from the common rule. Market anomalies happened in Bangladesh's capital market in two ways:

\section{Fundamental problems}

The primary market is affected by the illegal use of funds raised through initial public offerings (IPO's), institutional investors acting more like retail investors to make quick profit and the concocted audit reports produced in the absence of IFRS (International Financial Reporting Standard).

\section{Human-made problems}

Popularly known as market abuse or manipulation, this happens through Excessive Placement shares, issuance of rights shares, sponsor-directors' share holdings, BO (beneficiary owner) and omnibus account contamination, insider trading, forced selling and continuously changing the stock market policies.

Let us have a look at the substantial market swings

Table5.1

Synopsis of Placement Trading

\begin{tabular}{|c|l|c|c|c|c|c|}
\hline SL & \multicolumn{1}{|c|}{$\begin{array}{c}\text { Name of } \\
\text { the Company }\end{array}$} & $\begin{array}{c}\text { Face } \\
\text { Value }\end{array}$ & $\begin{array}{c}\text { Share } \\
\text { offload } \\
\text { in Tk } \\
\text { (Corers) }\end{array}$ & $\begin{array}{c}\text { Premium } \\
\text { In Each } \\
\text { Shares }\end{array}$ & $\begin{array}{c}\text { Tk with } \\
\text { Premium } \\
\text { (Corers) }\end{array}$ & $\begin{array}{c}\text { Total Tk } \\
\text { (Corers) }\end{array}$ \\
\hline 1 & GP & 10 & 65.69 & 64.00 & 420.39 & 486.08 \\
\hline 2 & Malek Spinning & 10 & 50.00 & 15.00 & 75.00 & 125.00 \\
\hline 3 & RAK Ceramics & 10 & 10.00 & 38.00 & 38.00 & 48.00 \\
\hline 4 & Mac sons Spinning & 10 & 12.00 & - & - & 12.00 \\
\hline 5 & United Airways & 100 & 50.00 & - & - & 50.00 \\
\hline 6 & Active Fine & 10 & 4.00 & - & - & 4.00 \\
\hline 7 & Orion Farma & 10 & 70.00 & 65.00 & 455.00 & 525.00 \\
\hline
\end{tabular}

\begin{tabular}{|c|l|c|c|c|c|c|}
\hline 8 & Unique Hotel & 10 & 30.00 & 150.00 & 450.00 & 480.00 \\
\hline 9 & GMG Airlines & 10 & 60.00 & 40.00 & 240.00 & 300.00 \\
\hline 10 & Energy Prime & 10 & 15.60 & 89.42 & 139.50 & 155.10 \\
\hline 11 & STS Holding & 10 & 86.98 & 5.00 & 43.49 & 130.47 \\
\hline 12 & Lanka Bangla Securities & 10 & 5.00 & 240.00 & 120.00 & 125.00 \\
\hline 13 & Keya Cotton Mills & 10 & 240.00 & 10.00 & 6.00 & 12.00 \\
\hline
\end{tabular}

In Table 5.1, we see a picture of placement share business in Bangladesh's capital market. The hectic activities relating to placement share business remind us of the 1996 kerb market. Thirteen companies offloaded placement shares including premiums and withdrew over Tk. 24.52 billion (2,452.65 corer) from Bangladesh's capital market. Source: The data presented in table (5.1-5.2) adapted from "Share Research"(Vol: 5; 25 April, 2011, page: 11-12). This is a publication of The institute of share research and training; A.K.M .Shamsul Alam, Editor of Share research; 15 Dilcusha, Arambug, Dhaka 1000.

Table5.2

Offloading Shares under Book building method

\begin{tabular}{|l|c|c|c|c|c|}
\hline $\begin{array}{c}\text { Name of the } \\
\text { Company }\end{array}$ & $\begin{array}{c}\text { Face } \\
\text { Value }\end{array}$ & $\begin{array}{c}\text { Share offload } \\
\text { in Tk (Corers) }\end{array}$ & $\begin{array}{c}\text { Premium in } \\
\text { Each Shares }\end{array}$ & $\begin{array}{c}\text { Tk with } \\
\text { Premium } \\
\text { (Corers') }\end{array}$ & $\begin{array}{c}\text { Total Tk } \\
\text { (Corers) }\end{array}$ \\
\hline MOBILJAMUNABD & 10 & 40.00 & 142.40 & 569.60 & 609.60 \\
\hline MICEMENT & 10 & 30.00 & 101.60 & 304.80 & 334.80 \\
\hline RAKCERAMICS & 10 & 34.51 & 38.00 & 131.14 & 165.65 \\
\hline
\end{tabular}

In Table 5.2, we see the companies offloaded shares with premium under the book building process, though controversial. Under the method, the companies increased the share prices abnormally. For instance, the three companies thus withdrew Tk 1,110.05 million from the share market

Table5.3

Different share market anomalies

\begin{tabular}{|l|c|c|c|c|c|}
\hline $\begin{array}{c}\text { Anomalies } \\
\text { (Based on } \\
\text { Year-2010)- }\end{array}$ & $\begin{array}{c}\text { Anomalies } \\
\text { through } \\
\text { Stock Spilt }\end{array}$ & $\begin{array}{c}\text { Anomalies } \\
\text { through } \\
\text { Demateria } \\
\text { lization }\end{array}$ & $\%$ & $\begin{array}{c}\text { Raising } \\
\text { money } \\
\text { through } \\
\text { Right } \\
\text { shares }\end{array}$ & $\%$ \\
\hline Company & $\begin{array}{c}\text { Abnormal } \\
\text { return }\end{array}$ & Company & $\begin{array}{c}\text { Abnormal } \\
\text { return }\end{array}$ & Company & $\begin{array}{c}\text { Fund Rise } \\
\text { (crore) }\end{array}$ \\
\hline CMC KAMAL & $71 \%$ & SAFKOSPINN & $304 \%$ & BAYLEASING & 1,071 \\
\hline FEDERALINS & $49 \%$ & CMCKAMAL & $156 \%$ & CONFIDCEM & 527 \\
\hline MEGHNACEM & $49 \%$ & MONNOSTAF & $141 \%$ & MERCANBAK & 1,439 \\
\hline ASIAINS & $41 \%$ & MONNOCERA & $111 \%$ & CITYBANK & 3,928 \\
\hline FIRSTBANK & $37 \%$ & HRTEX & $110 \%$ & ISLAMICFIN & 299 \\
\hline PLFSL & $35 \%$ & IMAMBUTTON & $94 \%$ & PRIMEBANK & 3,466 \\
\hline BDFINANCE & $32 \%$ & LIBRAINFU & $75 \%$ & GOLDENSON & 1,488 \\
\hline NCCBANK & $30 \%$ & RAHIMAFOOD & $75 \%$ & MAKSONSPIN & 2,622 \\
\hline PREMIER BANK & $27 \%$ & CTGVEG & $59 \%$ & NCCBANK & 1,142 \\
\hline
\end{tabular}

In Table 5.3, we see Bangladesh capital market experienced some major anomalies in market fundamentals in the areas of stock split, dematerialization and issuance of rights shares.

When it came to stock split, shares of nine companies out of 35 had posted unusual returns. In the area of dematerialization, nine companies, out of 32, saw unusual returns. Finally, the market witnessed speculation of share prices through issuance of rights shares. Nine companies out of 26 topped the list in raising funds from the market by offering rights shares.

Source: Table 5.3 adapted from DSE research unit (base year,2010)

\section{Other Sensitive Fundamental Issues}

Price-earning $(\mathrm{P} / \mathrm{E})$ ratio 
Investors have long argued that stocks with low priceearnings ratios are more likely to be underestimated and gain enough return. For example, Benjamin Graham has explained in his investment classic that intelligent investors use low price-earnings as a screen for funding underestimated shares. The logic behind the $\mathrm{P} / \mathrm{E}$ is that shares with low $\mathrm{P} / \mathrm{E}$ ratios generally involve low growth, large size, and secured business, all of which should work toward mitigating the risk factor rather than increasing it.

Table6.1

Status of P/E Ratio

\begin{tabular}{|c|c|}
\hline Name of the Country & By adopting Lowest P/E Stocks \\
\hline Australia & $3.03 \%$ \\
\hline France & $6.40 \%$ \\
\hline Germany & $1.06 \%$ \\
\hline Hong Kong & $6.60 \%$ \\
\hline Italy & $14.16 \%$ \\
\hline Japan & $7.30 \%$ \\
\hline Switzerland & $9.02 \%$ \\
\hline UK & $2.40 \%$ \\
\hline
\end{tabular}

The Table 6.1shows the annual premium earned over an index of equally-weighted stocks in those developed countries' markets between January 1, 1989 and December 31, 1994.

Source: Excess Returns on Low PE Ratio stocks by country (Investment Valuation by Aswath Damodaran: 2nd Edition, page 138)

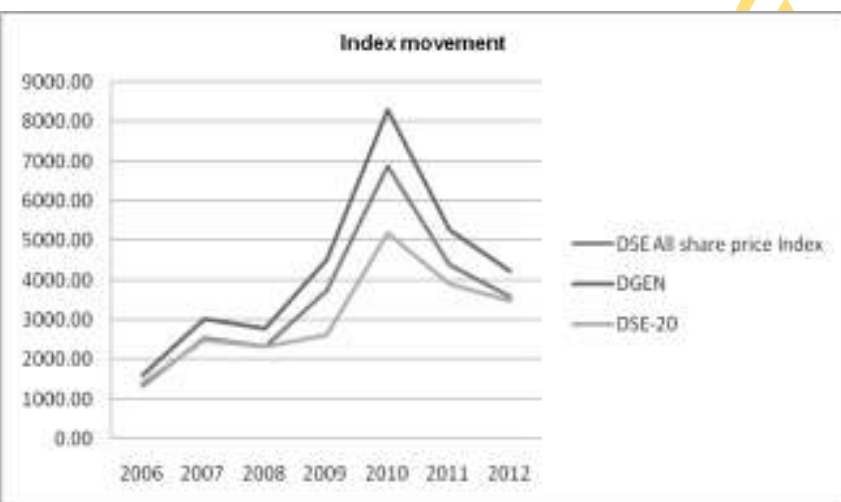

In the above figure, we see movement of the then all three DSE indexes during the time of the market crash, especially in 2010. In 2009, the DSE General Index was at 4,535 points. In 2010 , it just doubled to 8,290 points leading a formation of a bubble. The other indexes also saw a similar trend. All bubbles burst sooner or later. This DSE bubble also burst. All the indexes kept falling in the next consecutive years2011 and 2012. (Hossain, 2013)

Source: The figure based on different DSE market reviews and data gathered and prepare by the author.

\section{The Riddle of MaNipulation IN the Context OF BANGLADESH STOCK MARKET}

The scope of manipulation remains because of weaknesses in five main areas. The areas are: Step 1-Market regulation by the Bangladesh Securities and Exchange Commission (BSEC), Step 2-Deviations from fundamentals in primary and secondary markets, Step 3Unaware general investors, Step 4-Less diversification, and Step 5- Less sustainability in terms of liquidity and investor confidence.

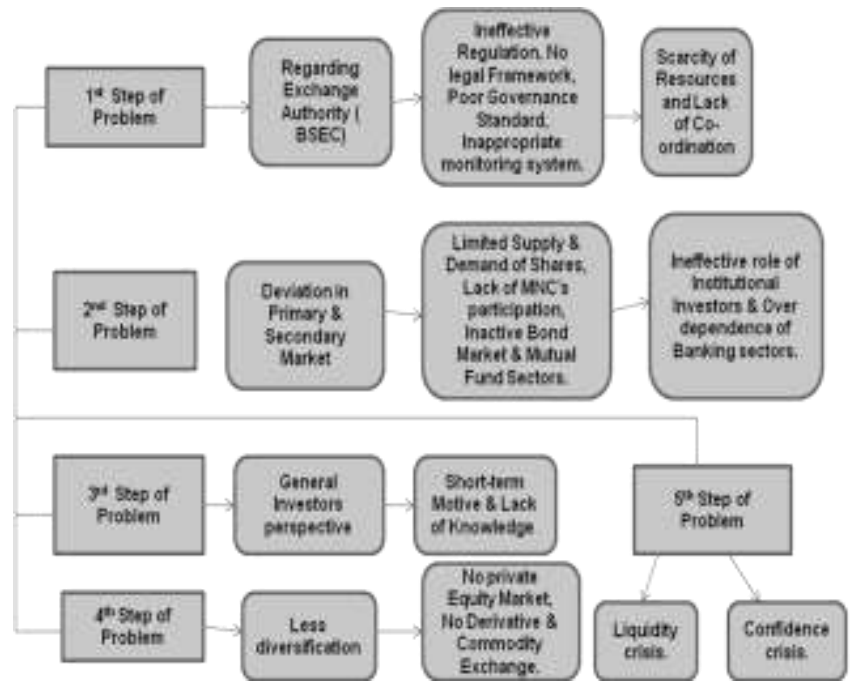

In the above figure, we see at a glance the problem chart in the Bangladesh stock market.

Source: The chart has been prepared by the writer himself with inputs from relevant sources

Step 1: The BSEC needs to concentrate on addressing the following deficiencies to ensure transparency in workings of the market

1) Ineffective regulation and absence of legal framework:

Before the beginning of the crash in 2010, the BSEC failed to play the regulatory role appropriately. For instance, the BSEC did not monitor the money market's involvement in the stock market. Nearly 32 commercial banks invested in the stock market the money that could be lent to the industrial sector. The BSEC could not do a check and balance. The money market could be totally separated from the stock market.

However, later on Dec 20, 2010 the Bank Company Act was enacted stipulating that a bank can invest the maximum $10 \%$ of its total deposits in the stock market. Still 16 banks violated that ceiling investing more than 10 per cent of their respective total deposits in the share market. That was a regulatory failure. Moreover, there is the absence of a proper legal framework. The Securities and Exchange Commission Ordinance, 1969 stipulates that any crime in the financial market invites five years' imprisonment or a fine of Tk 5 lakh, or both. This level of punishment is very insignificant. The law should be made more stringent. On the other hand, the government failed to take any punitive measures. That means there is no example of meting out punishment to anyone responsible for the stock market crashes in 1996 and in 2010-11.

2) Poor governance and the lack of IFRS (International Financial Reporting Standard): 
Bangladesh capital market was devastated by excessive manipulative activities both in 1996 and 2010-11. The market was badly hit by price sensitive information, wrong asset valuation by listed companies and so on. It occurred because of the poor corporate governance practice and the absence of the international financial reporting standard. Besides, the exchanges should set up their respective corporate governance departments for the listed companies. At the same time, it should be kept in mind that corporate governance and IFRS are interlinked. The corporate governance will not work, if the IFRS is not adopted. The transparency of listed companies' activities is not ensured, their viability in the market will suffer.

3) Scarcity of resources and improper monitoring system:

The BSEC has appeared as a useless regulator. At the time of the last market crisis, it constantly changed the margin rules and made the market volatile. It could not properly handle the lock-in period regarding the private placement of shares. Moreover, it lacks professionals like Chartered Financial Planners, Chartered Financial Analysts and International Auditors. So, imprudent monitoring and surveillance increased the chances of gambling inside the market.

4) Lack of Coordination:

The Ministry of Finance $(\mathrm{MoF})$, the BSEC and the Bangladesh Bank (BB) lack the required level of coordination among themselves in the areas of regulatory role, function, management and governance in the capital market.

Step 2: Manipulation/Deviation from fundamentals in primary and secondary markets

1) Tampering with prices of shares:

In cricket, dishonest players tamper with the ball for swinging it and taking wickets. In the capital market also there are some greedy people buying large volumes of shares at low prices and creating an artificial crisis inside the market and then during a crisis period again those people sell their shares at higher prices. This type of unethical practices leaves the secondary market overheated. On the other hand, in the primary market any abnormal rise in share prices happens through manipulation of IPOs (initial public offering) and pre-IPOs.

2) Inactive role of institutional investors and other sectors' participation:

Firstly, financial institutions and big players in the capital market behave more like retailers or small investors. For example, just with the intention of rapid profit making, many banks and non-banking financial institutions (NBFIs) started investing in the share market without bearing in mind any limit of such investments. In early 2009 and before December in
2010, many banks and NBFIs invested in the capital market far exceeding their exposure limit. Secondly, the presence of bonds in the capital market is too thin. Only two government bonds, and one bond of the Islamic Bank are in the market. On the other hand, though mutual funds (MFs) saw a turnaround in 2012 and then improved further in 2013, they still need to play a more active role in the capital market.

\section{3) Supply-side and demand-side problems:}

The supply-side constraints happen because of the lack of a comprehensive IPO policy. For example, without being listed with any of the exchanges, some companies floated IPOs in violation of the IPO policy, as the policy did not specify any fine or any other form of punishment in this connection. Because of the procedural breach, the market missed good stocks. So when the demand for shares increased, the supply didn't.

On the other hand, the presence of multinational companies (MNCs) in the local capital market is not at all satisfactory. If the MNCs' participation can be enhanced, it will ensure availability of some good stocks in the market. Another area of concern is the lack of adequate government bonds. If the bond market is developed, funds can be raised from there during any crisis period of the share market without depending on the government's stimulus package. It will lessen pressure on the share market for raising funds.

A large number of commercial banks are in the capital market. Gradually banks have become the key players and dominated the stock market. Perhaps, the Bangladesh Bank (BB) was not much aware of the banks' exposure to the stock market during the crisis period of 2010-11. It was true that the asset price bubble was created by the excessive trading of commercial banks in the stock market.

\section{Step 3: The problem of unaware general investors}

A lot of greedy small investors had entered the share business to become rich overnight before the last debacle. They had invested in the capital market without proper planning and market-related knowledge. They all thought of short-term gains, not long-term.

\section{Step 4: Less diversification}

Bangladesh share market is struggling in the absence of proper risk diversification instruments like financial derivatives. There are also no private equity markets, Islamic stock market and so on.

Both the stock exchanges are now going for demutualization. Obviously, demutualisation is not the ultimate solution to the market manipulation. Demutualization will only help reduce the conflict of interest in the capital market and the traditional thinking of listed companies' directors and chairmen. Alongside demutualisation, the authorities must establish a financial 
market discipline committee and a financial reporting council to reap the full benefit of demutualised exchanges.

\section{Step 5: Less sustainability}

At present, the crucial problem in the local capital market is the confidence crisis, not money. Till now manipulation is going on in the share market. So the market is failing to restore the investor confidence and losing sustainability.

The authorities have to fight on all fronts as stated above to put an end to the scope of manipulation at different levels in the local stock market.

Now let's present some examples of how acts of manipulation took place in the share market of Bangladesh. The prices were raised abnormally to trap small investors.

\section{Case analysis 1:}

From this case study, we learn how the abnormal stock price fluctuation happened in the local capital market, and the unaware and innocent small investors were attracted to invest there.

Table 7.1

Trend of rising share price

\begin{tabular}{|l|c|c|c|c|c|}
\hline Name of Companies & $\begin{array}{c}\text { Face } \\
\text { Value }\end{array}$ & $\begin{array}{c}\text { Market price } \\
\text { on Jan 4, 2009 }\end{array}$ & $\begin{array}{c}\text { Highest } \\
\text { market } \\
\text { price }\end{array}$ & $\begin{array}{c}\text { The highest } \\
\text { price date }\end{array}$ & $\begin{array}{c}\text { Change } \\
\text { in \% }\end{array}$ \\
\hline Chittagong Vegetables & 100 & 26.25 & $6,699.00$ & 6 Jan 2011 & 25420 \\
\hline Bitch Hatchery & 10 & 5.80 & 125.50 & 1 Dec 2010 & 2,063 \\
\hline Tallu spinning & 100 & 64 & 1273.75 & 23 Nov 2010 & 1890 \\
\hline Purobi Insurance & 100 & 170 & 2835 & 5 Dec 2010 & 1567.65 \\
\hline Rahim Food & 100 & 54.75 & 880.00 & 23Nov2010 & 1507.31 \\
\hline Mithun Knitting & 100 & 176.75 & 2557.00 & 23 Nov 2010 & 1346.68 \\
\hline BD Welding & 10 & 25.30 & 275.90 & 26 Dec 2010 & 990.51 \\
\hline Meghna Condensed milk & 10 & 9.20 & 96.90 & 2Dec 2010 & 953.26 \\
\hline HR Textile & 100 & 113.50 & 1169.75 & 23 Nov 2010 & 930.62 \\
\hline Delta Life & 100 & 12123.00 & 40699.00 & 4 Jan 2011 & 235.72 \\
\hline Mercantile Insurance & 100 & 209.25 & 1749.00 & 5Dec 2010 & 735.84 \\
\hline Prime Textile & 100 & 125.50 & 1037.75 & 5Dec 2010 & 726.89 \\
\hline Meghna Pet & 10 & 4.00 & 33.00 & 5Jan2011 & 725.00 \\
\hline Paramount insurance & 100 & 149.75 & 1194.00 & 5Dec 2010 & 697.33 \\
\hline Rahim Textile & 100 & 418.00 & 3300.00 & 2Jan2011 & 689.47 \\
\hline Shamrita Hospital & 100 & 250.00 & 1950.00 & 4 Nov 2010 & 680.00 \\
\hline Continental Insurance & 100 & 193.75 & 1280.00 & 6 Dec 2010 & 560.65 \\
\hline Janata Insurance & 100 & 366.50 & 2400.00 & 5 Dec 2010 & 554.84 \\
\hline Ambee Pharma & 100 & 129.50 & 843.00 & 23 Nov 2010 & 521.36 \\
\hline Jamuna Oil & 10 & 141.80 & 427.00 & 31 Oct 2010 & 201.13 \\
\hline The table 7.1 & & & & \\
\hline
\end{tabular}

The table 7.1, here shows the prospective companies took their share prices to the sky-high. They did it artificially. Still the BSEC did not feel the necessity of looking into the company fundamentals, their managerial efficiency, net asset value, $\mathrm{P} / \mathrm{E}$ (price earnings) ratio and business growth. Any tree can aim at the sky. But those companies had a tendency to take their share prices beyond the sky. Obviously, there is a limit of fundamentals. But those companies did not abide by the limit.

\section{Case analysis 2:}

Table 7.2

Scenario's of Profit booking

\begin{tabular}{|c|l|c|c|}
\hline S1 No. & \multicolumn{1}{|c|}{ Particulars } & $\begin{array}{c}\text { Total Amount } \\
\text { in corer }\end{array}$ & Taka in Destiny \\
\hline 1 & $\begin{array}{l}\text { Listing Public Companies } \\
\text { with Premium }\end{array}$ & $2,028.79$ & Public Treasury \\
\hline
\end{tabular}

\begin{tabular}{|c|l|c|c|}
\hline 2 & $\begin{array}{l}\text { Listing Private Companies } \\
\text { with Premium }\end{array}$ & $1,996.51$ & Sponsors \\
\hline 3 & $\begin{array}{l}\text { IPO's \& Placement with } \\
\text { Premium }\end{array}$ & $1,636.11$ & Deposit in Company \\
\hline 4 & Repeat IPO & 10.00 & Deposit in Company \\
\hline 5 & $\begin{array}{l}\text { Listing with Book Building } \\
\text { Method including Premium }\end{array}$ & $1,110.05$ & Deposit in Company \\
\hline 6 & Placement and IPO's of MF & $1,683.50$ & Deposit in Company \\
\hline 7 & Withdraw with Right Shares & $2,617.17$ & Deposit in Company \\
\hline 8 & Preference Shares & $1,162.98$ & Deposit in Company \\
\hline 9 & Converting Loan into Equity & 645.95 & Deposit in Company \\
\hline 10 & $\begin{array}{l}\text { Selling Shares of Directors/ } \\
\text { Entrepreneurs }\end{array}$ & $3,765.65$ & sponsors \\
\hline 11 & $\begin{array}{l}\text { Banks, Insurance \& Others } \\
\text { Corporate Investors }\end{array}$ & $7,000.00$ & Regarding Institution \\
\hline 12 & $\begin{array}{l}\text { Private Placement with prem } \\
\text { ium (Uncertainty of listing) }\end{array}$ & $1,727.57$ & Deposit in Company \\
\hline 13 & $\begin{array}{l}\text { Foreign companies } \\
\text { withdraw profit }\end{array}$ & $1,203.00$ & Outside of the country \\
\hline 14 & Sub-Total & $26,586.56$ & \\
\hline 15 & $\begin{array}{l}\text { Investors withdraw profit with } \\
\text { lawfully and unlawfully }\end{array}$ & 34,000 & \\
\hline & Total & $60,586.56$ & \\
\hline
\end{tabular}

In the table 7.2 , we see nearly Tk 60,586 corers were withdrawn from the stock market of Bangladesh in different forms of profit booking during the market crash in 2010-11.

Source: The data presented in table (7.1- 7.2) adapted from "Share Research"(Vol: 5; 25 April, 2011, page: 10-14). This is a publication of The institute of share research and training; ;A.K.M .Shamsul Alam, Editor of Share research; 15 Dilcusha, Arambug, Dhaka 1000.

\section{Case analysis 3:}

Table 7.3

Trend of Assets Revaluation

\begin{tabular}{|c|l|c|}
\hline S1 No & Name of Company & Assets Revaluation \\
\hline 1. & Libra Infusion & $3472 \%$ \\
\hline 2. & Sonali Jute Industry & $626 \%$ \\
\hline 3. & Rahim Textile & $518 \%$ \\
\hline 4. & BD Thai \&Aluminium & $298 \%$ \\
\hline 5. & Orion Infusion & $413 \%$ \\
\hline 6. & Ocean Containers & $296 \%$ \\
\hline 7. & Shinepukur Ceramics & $120 \%$ \\
\hline
\end{tabular}

In the table 7.3, we see the seven companies revalued their assets leaving their stock prices overheated due to the lack of a surveyor institution. There is no surveyor institution in Bangladesh. In developed countries, the company asset revaluation is done by the surveyors. But in Bangladesh the firm that audits the company also accounts does the company's asset revaluation. So there is a chance of overestimating the company assets. The surveyor institution and the auditor should be different persons as in the developed world.

Source: The data represented in table 7.36. adapted from the Prothom Alo, 8 April, 2011

\section{Case analysis 4:}

Share prices rose abnormally beyond the price band as set under the Book Building Method. 


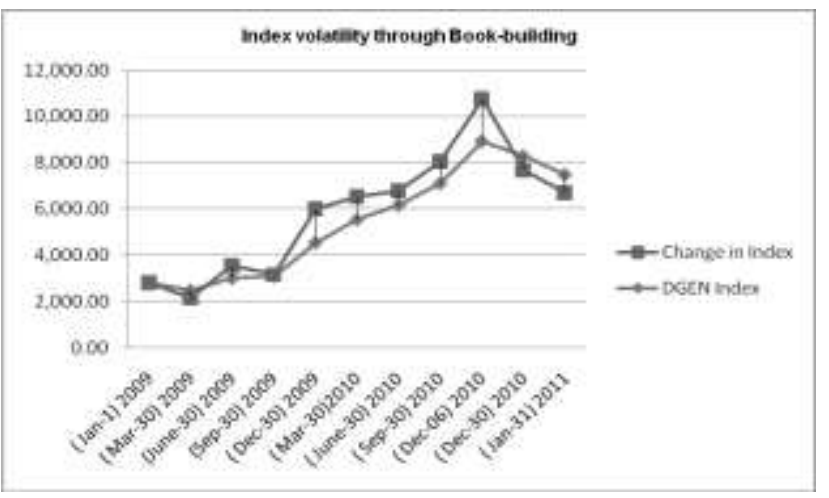

In the FIG-7.1, we see our stock market was overpriced due to overvaluation of secondary and primary markets that happened defying the book-building method. For example, the face value of KPPL was Tk 10. The share value was set at Tk 162 under the book building method. But the share value rose to Tk 194 on the very first day, far beyond the price band set under the book building method. Only the RAK Ceramics followed the book-building method properly while the KPCL flouted it. The graph clearly shows the DSE General Index (DGEN) rose day by day creating a continued demand in the share market. It could have helped leave the market overheated.

Source: The figure 7.1 based on different DSE market reviews and data gathered and prepare by the author.

\section{FINDINGS OF THE STUDY}

According to CPD working paper, the big players who were behind the 1996 market crash were still active and played a major role in prompting the market debacle in 2010-11. For instance, suspicious transactions were made by the nexus of big players including individuals and institutional investors as top buyers and sellers. They were involved in market manipulation through different ways such as offering excessive placement shares before initial public offerings (IPOs); manipulation through $\mathrm{B} / \mathrm{O}$ and omnibus account; unlawfully they worked for some fraudulent companies and convinced the regulatory body to lift the lock in period in favor of them.

Moreover they acted with their speculative motive to artificially raise the ' $Z$ ' category shares.

In addition, specific findings of this study includes

- The large block of stock holders particularly known as institutional investors also became greedy along with retail investors.

- The five steps of problem or structural weakness produced both the fundamental deviation and the riddle of manipulation.

- The stock market in our economy, small in size and lacks proper awareness and education among the investors the basic principles of stock market fundamentals.

\section{Bangladesh Share market Looking Ahead}

Some numerous steps were taken from regulator side. That are-
- $\quad$ Restructuring of the SEC;

- $\quad$ Stock exchange demutualization;

- Reducing banks exposure in Share market;

- Taking stock refinancing scheme;

- Introducing new stock indices;

- Enhancing better co-ordination between the SEC and stock exchanges;

- Adapting new software surveillances system for better regulation;

- $\quad$ Setting up of specific policy for pre-IPO placement;

- Ensuring transparency in dealing with Omnibus Accounts,

- Restraining share trading by some government officials;

- Ensuring monitoring activities. For instance, SEC review of asset revaluation by companies, review of the book-building method of IPO, making uniform face-value of all companies and taking legal actions against market players/manipulators.

At present (the year 2013), the Share market has turned back and is getting stable to some extent.

\section{Conclusions}

Experts and economists view the capital market in Bangladesh as a frontier market, small in size. It is easy to manipulate such a small market. So there must be a discipline committee comprising foreign experts, who will look into the aspect of market discipline.

It is high time for the government and the share market regulators to take some pragmatic measures in light of what have been stated above to put an end to the scope of manipulations and found the market on a sound footing. Moreover, anomalies follow inefficiencies in the market. So, the capital market anomalies do play a vital part in devastating the market to the maximum extent. However, the market authorities consider the possible effects of market mechanism, especially to strictly monitor the listed companies' activities.

Finally, one must bear in mind that any investment in the stock market is never risk-free. The authorities never publish any circulars inviting people to invest in the share market. So the investors must be well-informed before making any investment decisions. The risk is always there, though it is true if the manipulators of market in 1996 and then in 2010-11 were punished, it might not happen again. One can forget the shock of losing a son, but not the loss of money.

There is no scope of showing negligence or mercy to the manipulators. Now it is time to show zero tolerance in the event of any share market fraud and frame guidelines with that end in view. Last but not the least, the government in no way should get involved in the market workings. The market should be let function in its own way. So it is a big challenge for the government in the years to come. 


\section{REFERENCES}

Abdullah MN, Parvez K and Khaled M. 2012. Is the Stock Market Overvalued: A Study in the Context of Bangladesh? Asian Business Review, 1, 30-36.

Aggarwal, Rajesh K., Wu, Guojun.( 2006), The University of Chicago, vol. 79, no. 4, 1-15

Aziz MS and Uddin MN. 2014. Volatility Estimation in the Dhaka Stock Exchange (DSE) returns by Garch Models Asian Business Review, 4, 41-49.

Bepari, M. Khokan. , Mollik, Abu. Bangladesh stock market growing? Key indicators based assessment.

Bhattacharya, D. Rahman, M., Khatun, F., Moazzem, K. G., Iqbal, Md. Ashiq. , Khan, Tawfiqul. Islam, Nabi, Ashiqun. (June 4, 2011). Analytical Review of Bangladesh's Macroeconomic Performance in Fiscal Year 2011-12, Second Reading, 45-64.

Bhattacharya, D. Rahman, M., Khatun, F., Moazzem, K. G., Iqbal, Md. Ashiq., Khan, Tawfiqul. Islam., Nabi, Ashiqun. (January 4, 2011). Analytical Review of Bangladesh's Macroeconomic Performance in Fiscal Year 2011-12, First Reading, 71-86.

Galbraith, J.K.(2009).The Great crash 1929, Houghton Mifflin Harcourt, Boston, New York, 66-88

Haque, M. S., (n.d.). Recent stock market crash in Bangladesh. [Internet], Available from:< http://www.nub.ac.bd/recent-stock-marketcrash-in-bangladesh-wrong-signals-from-responsible-quarterssince-the-ctg-caused-the-asset-price-bubble/>

Hossain M T., 2011. Stock market crashes of 1996 and 2011. [Internet], Available from http:/ / www.hawker.com.bd/news_details.php?news_id=1 43942\&news_category_id=14\&val_lan=

Hossain Md. Toufique, Bangladesh stock market crisis: diagnosis, remedies, prospects, OP-ED, Tuesday, December 27,2011 http://newagebd.com/newspaper1/archive_details.php?d ate $=2011-12-26 \&$ nid $=44728$

Hossain Md. Toufique, Bangladesh stock market: understanding the trends, VOL 21, NO -162 REGD NO DA 1589, http:/ / www.thefinancialexpress-bd.com/old/more.php? news_id=171030\&date=2013-05-30.

Hossain Md. Toufique, Dhaka Stock Exchange: panic, fascination and trouble, OP-ED, Wednesday, December 14, 2011 http:/ / archive.thedailystar.net/newDesign/newsdetails.php?nid=213982

Hossain Md. Toufique, Two bubble-and-bust episodes in capital market, VOL 18, NO -267 REGD NO DA 1589, http:/ / www.thefinancialexpressbd.com/more.php? news_id=144533\&date $=2011-07-31$.

Huda SN. 2013. Intensifying of Stock Markets (DSE \& CSE) in Bangladesh: An Experiment Asian Business Review, 2, 44-50.

Islam Mirza Azizul: Bangladesh scenario: Bubbles and busts, Financial Express, June 26/2014. See http:/ / www.thefinancialexpress-bd.com/2014/06/26/41532/print.
Kindleberger, Charles. P. ( $5^{\text {th }}$ Edition) Manias, Panics, and Crashes, A History of Financial Crises, 24-63

Ledgerwood. Shaun D., Carpenter. Paul R (DOI: 10.1515/15555879.1577). A Framework for the Analysis of Market Manipulation, 1-10

Mansur A., 2010. Is the Bull Market Sustainable? Volume 3 Issue 4, The daily star.[Internet], Available from: http://www.thedailystar.net/forum/2010/april/bull.htm

Maxim MR, Miti TA and Arifuzzaman SM. 2013. Is Dhaka Stock Exchange (DSE) Efficient? A Comparison of Efficiency Before and After the Market Crisis of 2010 Asian Business Review, 3, 78-81.

Rahman J., 2011. Share Market Bubble - the Big Picture. [Internet], Available from: http:/ /dpwriters.wordpress.com/2011/02/04/sharemarket-bubble-the-big-picture/

Siegel, Jeremy. J., (2003). What is an Asset price bubble? An operational Definition, Vol., 9, 1-5

\section{Websites}

Bangladesh Bank, http://www.bangladesh-bank.org/

Central Depository Bangladesh Limited, http:/ / www.cdbl.com.bd/

Chittagong Stock Exchanges, http://www.cse.com.bd/

Dhaka Stock Exchanges, http:/ /www.dsebd.org/

Bangladesh Security and exchange commission, http://www.sec.gov.bd/

\section{Abbreviation}

$\mathrm{B} / \mathrm{O}$ Account $=$ Beneficiary Owners account

DSE $=$ Dhaka stock exchange

$\mathrm{CSE}=$ Chittagong stock exchange

SEC $=$ Securities and Exchange Commission

BSEC $=$ Bangladesh Security and Exchange Commission

DGEN = DSE general index

DSI= DSE All Share Price Index

CASPI $=$ CSE all share price index

$\mathrm{CSCX}=\mathrm{CSE}$ selective categories index

OTC $=$ Over- the - Counter Market

$\mathrm{CDBL}=$ Central Depository Bangladesh ltd

DGEN = DSE- General Price Index

$\mathrm{P} / \mathrm{E}=$ Price Earnings Ratio

EPS=Earnings per Share

$\mathrm{M} 1=$ narrow money

M2=Broad Money

$\mathrm{CRR}=$ Cash Reserve Ratio

$\mathrm{SLR}=$ Statutory Liquidity Ratio

IPOs= Initial Public Offering

$\mathrm{BB}=$ Bangladesh Bank

$\mathrm{MoF}=$ Ministry of Finance

DMAT $=$ Dematerialization

$\mathrm{CPD}=$ Centre for Policy Dialogue

\section{How to Cite}

Hossain MT. 2014. The Fundamental Deviation and the Riddle of Manipulation: A Critical Analysis in the Context of Bangladesh Stock Market Crash in 2010-11 Asian Business Review, 4, 92-99. 